Upaya Meningkatkan Menulis.... (Eppy Marlina)

\title{
UPAYA MENINGKATKAN MENULIS KARANGAN NARASI SISWA SMPN 2 BUAY BAHUGA MELALUI PENERAPAN STRATEGI PEMBELAJARAN INQUIRI DENGAN MEDIA GAMBAR
}

\author{
Oleh: Eppy Marlina \\ (Guru SMP Negeri 2 Buay Bahuga, Lampung) \\ Email: eppymarlina@gmail.com
}

\begin{abstract}
Abstrak
Masalah dalam penelitian ini adalah bagaimanakah proses pembelajaran menulis karangan narasi siswa kelas VII SMPN 2 Buay Bahuga melalui penerapan strategi pembelajaraan inquiri dengan media gambar dan hasil peningkatan kemampuan menulis karangan narasi siswa. Metode yang digunakan adalah metode penelitian tindakan kelas yang dilaksanakan di SMPN 2 Buay Bahuga dan yang menjadi subjek penelitian ini adalah siswa kelas VII SMPN 2 Buay Bahuga, dengan jumlah sebanyak 33 siswa. Teknik pengumpulan data yang digunakan pada penelitian ini adalah teknik tes, observasi, dan angket. Berdasarkan hasil penelitian bahwa penggunaan metode pembelajaran inquiri pada pembelajaran Bahasa Indonesia dalam menulis karangan narasi dapat meningkatkan keterampilan siswa dan dapat membantu siswa dalam mengembangkan imajinasinya dibuktikan dari hasil mengarang siswa dari prasiklus sampai siklus II. Siswa yang tuntas pada saat prasiklus adalah 9 siswa atau 27\%. Pada siklus I, meningkat menjadi 19 siswa atau 57,5\% dengan nilai rata-rata 71,9. Pada siklus II siswa yang tuntas 32 siswa atau 96,7\% dengan nilai rata-rata 76,96 .
\end{abstract}

Kata Kunci: Karangan Narasi, Strategi Pembelajaran Inquiri, Media Gambar

\section{IMPROVEMENT OF STUDENT LEARNING ABILITIES USING APPROACH TOOLS IN SDN PABUARAN 2 KOTA TANGERANG}

\begin{abstract}
The problem in this research is how is the process of learning to write narrative essays for VII grade students of SMPN 2 Buay Bahuga through the application of inquiry learning strategies with image media and the results of improving students' narrative essay writing skills. The method used was a classroom action research method carried out at SMPN 2 Buay Bahuga and the subject of this study was Grade VII students of SMPN 2 Buay Bahuga, with a total of 33 students. Data collection techniques used in this study were test, observation, and questionnaire techniques. Based on the results of research that the use of inquiry learning methods in learning Indonesian in writing narrative essays can improve student skills and can help students develop their imagination proven from the results of composing students from pre-cycle to cycle II. Students
\end{abstract}


who completed the pre-cycle were 9 students or 27\%. In the first cycle, it increased to 19 students or $57.5 \%$ with an average grade of 71.9. In cycle II students completed 32 students or $96.7 \%$ with an average grade of 76.96 .

Keywords: Narrative Essay, Inquiry Learning Strategies, Image Media

\section{A. PENDAHULUAN}

Keterampilan menulis merupakan kegiatan yang harus dikuasai oleh siswa. Setiap siswa harus memiliki kemampuan menulis karangan berdasarkan pengalaman dengan memperhatikan ejaan dan pilihan kata. Pada kenyataan aktivitas menulis ini tidak banyak dikuasai oleh peserta didik karena kegiatan menulis dianggap rumit. Hal ini terlihat masih banyak peserta didik yang memperoleh nilai menulis di bawah kriteria ketuntasan minimal sekolah. Semi (2007:3) menulis tidaklah sulit, tetapi tidak pula gampang. Menulis sebagai salah satu aspek keterampilan berbahasa merupakan suatu hal yang sangat penting untuk diajarkan kepada siswa.

Salah satu cara untuk mengatasi kekurangberhasilan tersebut dapat dilakukan dengan penerapan strategi pembelajaraan inquiri dengan media gambar. Berdasarkan permasalahan di atas, maka peneliti berupaya untuk meningkatkan keterampilan menulis karangan narasi siswa kelas VII SMP N 2 Buay Bahuga, Lampung melalui penerapan strategi pembelajaran inquiri dengan media gambar.

Masalah dalam penelitian adalah; 1) Peningkatan kemampuan menulis karangan narasi melalui penerapan strategi pembelajaran inquiri; 2) Media yang digunakan adalah media gambar; 3) Materi pembelajaran yang digunakan dalam penelitian ini adalah menulis karangan narasi; 4) Siswa yang diteliti adalah siswa kelas VII SMP N 2 Buay Bahuga, Lampung.

Tujuan dalam penelitian ini untuk mengetahui dan mendeskripsikan proses pembelajaran dan hasil peningkatan kemampuan menulis karangan narasi siswa kelas VII SMP N 2 Buay Bahuga, Lampungmelalui penerapan strategi pembelajaran inquiri dengan media gambar. 
Upaya Meningkatkan Menulis.... (Eppy Marlina)

Rahardi (dikutip Kusumaningsih, 2013:65) menulis adalah kegiatan menyampaikan sesuatu menggunakan bahasa melalui tulisan, dengan maksud dan pertimbangan tertentu untuk mencapai suatu yang dikehendaki. Armariena (2017) menulis merupakan keterampilan bahasa untuk berkomunikasi secara tidak langsung. Menulis sebagai salah satu kemampuan berbahasa, membutuhkan keahlian dari seseoran dalam menguasai bentuk bahasa tulis untuk suatu maksud (Keraf, 2001:42).

Pada dasarnya tujuan menulis adalah sebagai alat komunikasi dalam bentuk tulisan. Setiap jenis tulisan tentunya memiliki tujuan. Menulis haruslah mempunyai tujuan yang nyata dan para penulis harus bisa meyakinkan, memberitahu, menghibur, dan mengekspresikan emosi (Armariena, 2015).

Karangan Narasi adalah sebuah karangan yang menceritakan suatu rangkaian kejadian yang disusun secara urut sesuai dengan urutan waktu. Menurut Slamet (2007:103), karangan narasi adalah ragam wacana yang menceritakan proses kejadian suatu peristiwa. Pendapat lain diungkapkan oleh Armariena (2017) bahwa pengertian narasi adalah bentuk wacana yang sasaran utamanya adalah tindak tanduk yang dijalin dan dirangkaikan menjadi sebuah peristiwa yang terjadi dalam suatu waktu.

Langkah-langkah menyusun narasi dilakukan melalui proses kreatif, dengan mencari, menemukan, dan menggali ide. langkah-langkah menulis karangan narasi adalah sebagai berikut. 1) Tentukan dulu tema dan amanat yang akan disampaikan; 2) Tetapkan sasaran pembaca kita; 3) Rancang peristiwa-peristiwa utama yang akan ditampilkan dalam bentuk skema alur; 4) Bagi peristiwa utama itu ke dalam bagian awal, perkembangan, dan akhir cerita; 5) Rincian peristiaperistiwa uatama ke dalam detail-detail peristiwa sebagai pendukung cerita; 6) Susun tokoh dan perwatakan, latar, dan sudut pandang (Armariena, 2019).

Strategi pembelajaran merupakan suatu serangkaian rencana kegiatan yang termasuk di dalamnya penggunaan metode dan pemanfaatan berbagai sumber daya atau kekuatan dalam suatu pembelajaran. Di lain pihak Dick dan Carey 
(2005:7) Strategi pembelajaran adalah komponen-komponen dari suatu set materi termasuk aktivitas sebelum pembelajaran, dan partisipasi peserta didik yang merupakan prosedur pembelajaran.

Pembelajaran inquiri merupakan kegiatan pembelajaran yang melibatkan secara maksimal seluruh kemampuan siswa untuk mencari dan menyelidiki sesuatu secara sistematis, kritis, logis, analitis sehingga mereka dapat merumuskan sendiri penemuannya dengan penuh percaya diri. Sanjaya (2008:196) berpendapat bahwa "strategi pembelajaran inquiri adalah rangkaian kegiatan pembelajaran yang menekankan pada proses berpikir secara kritis dan analitis untuk mencari dan menemukan sendiri jawaban dari suatu masalah yang dipertanyakan".

Sadiman (2003:21), media gambar adalah suatu gambar yang berkaitan dengan materi pelajaran yang berfungsi untuk menyampaikan pesan dari guru kepada siswa. Media gambar ini dapat membantu siswa untuk mengungkapkan informasi yang terkandung dalam masalah sehingga hubungan antar komponen dalam masalah tersebut dapat terlihat dengan lebih jelas.

Tujuan penggunaan media gambar dalam pembelajaran adalah: (1) menerjemahkan simbol verbal, (2) menkonkritkan dan memperbaiki kesan-kesan yang salah dari ilustrasi lisan, (3) memberikan ilustrasi suatu buku, dan (4) membangkitkan motivasi belajar dan menghidupkan suasana kelas.

\section{B. METODOLOGI PENELITIAN}

Metode yang digunakan adalah metode penelitian tindakan kelas. Penelitian ini terdiri atas empat kegiatan, yaitu perencanaan, pelaksanaan, observasi, dan refleksi. Subjek penelitian ini adalah Siswa kelas VII SMPN 2 Buay Bahuga, Lampung, yaitu kelas VII.2 yang berjumlah 33 Orang

Dalam penelitian ini menggunakan teknik tes, teknik observasi, dan teknik dokumentasi. Lembar kerja, hasil tes dan nilai akhir merupakan dokumentasi yang akan digunakan sebagai pelaporan. Data dikumpulkan dari pelaksanaan setiap 
Upaya Meningkatkan Menulis.... (Eppy Marlina)

siklus dan dianalisis secara deskriptif dengan menggunakan teknik analisis data tes, teknik analisis data observasi, dan teknik analisis data dokumentasi.

\section{HASIL PENELITIAN DAN PEMBAHASAN}

Untuk memperoleh data mengenai kemampuan menulis karangan narasi siswa kelas VII SMP N 2 Buay Bahuga, Lampung melalui penerapan strategi pembelajaran inquiri dengan media gambar, siswa diminta membuat karangan narasi dengan gambar yang ada.

Tes awal dilakukan pada tanggal 13 Oktober 2019 hasil yang didapat yakni dari 33 siswa yang nilai $\geq 75$ sebanyak 10 orang, sedangkan yang nilai $\leq 75$ sebanyak 23 orang. Peneliti melakukan penelitian tindakan kelas.

Siklus pertama dilakukan dalam dua kali pertemuan. Siklus I dilakukan sebagai usaha untuk mengatasi masalah yang ditemukan pada saat observasi awal. Siklus I dilaksanakan selama 2 kali pertemuan. Pertemuan pertama yaitu pada hari Selasa tanggal 13 Oktober 2015 selama 2 jam pelajaran pada pukul 07.30-08.40 WIB. Pertemuan kedua dilaksanakan pada hari Jum'at tanggal 16 Oktober 2015 selam 2 jam pelajaran adalah 70 menit, pada pukul 07.30-08.40 WIB.

Pertemuan I dilaksanakan pada hari Selasa tanggal 13 Oktober 2015 pada pukul 07.30-08.40 WIB. Pelaksanaan terdiri dari kegiatan awal, kegiatan inti dan kegiatan akhir pembelajaran ditutup doa. Pertemuan kedua dilaksanakan pada hari Jum'at tanggal 16 Oktober 2015. Proses pembelajaran dimulai pukul 07.30-08.40 WIB. Kegiatan dimulai dengan kegiatan awal dilanjutkan kegiatan inti kemudian diakhiri dengan kegiatan penutup.

Pada observasi aktivitas guru meliputi apersepsi, penjelasan materi, penjelasan model pembelajaran sampai dengan menyimpulkan dan menutup pelajaran. Dan pada observasi aktivitas siswa menunjukkan kategori kurang aktif karena masih ada beberapa mendapatkan nilai rendah. Pada evaluasi hasil belajar dengan nilai rata-ratanya 72,1. Siswa yang mencapai KKM berjumlah 19 siswa, atau 59,3\%. Sedangkan yang belum mencapai KKM sebanyak 14 siswa $(40,7 \%)$ 
dan mengalami peningkatan yang signifikan tetapi belum mencapai ketuntasan klasikal yaitu $70 \%$.

Siklus II dilaksanakan sesuai dengan hasil refleksi dari kekurangan dan kelebihan pada siklus I sebagai usaha perbaikan. Perbaikan-perbaikan pada siklus I akan dilakukan pada Siklus II dengan perencanaan pertemuan pertama dilaksanakan pada hari Selasa tanggal 20 Oktober 2015, pukul 07.30-08.40 WIB. Pertemuan kedua dilaksanakan pada hari Jum'at tanggal 23 Oktober 2015 pukul 07.30-08.40 WIB.

Pertemuan pertama di siklus II dilakukan pada hari Selasa tanggal 20 Oktober 2015. Pembelajaran dimulai pada pukul 07.30 WIB dan diakhiri pada pukul 08.40 WIB. Pertemua kedua dilaksanakan pada hari Jum'at tanggal 23 Oktober 2015. Pembelajaran dimulai pada pukul 07.30 WIB dan diakhiri pada pukul 08.40 WIB. Kegiatan dimulai dengan kegiatan awal dilanjutkan kegiatan inti dan kegiatan ditutup pada kegiatan akhir.

Pada aktivitas guru selama proses pembelajaran telah sesuai dengan prosedur rencana pelaksanaan pembelajaran dan observasi aktivitas siswa pada kategori sangat aktif. Pada evaluasi siswa didapat hasil siswa yang memperoleh nilai $\geq 70$ mencapai 32 siswa telah mencapai kriteria ketuntasan minimal klasikal yakni 96,7\%. dari total 33 siswa dan sisanya memperoleh nilai $<70$ sebanyak 1 siswa.

Hasil analisis data tes secara keseluruhan berdasarkan analisis data siklus 1, dan siklus 2, dapat diketahui bahwa siswa yang mendapat nilai $<70$ yaitu 67 tergolong belum tuntas sebanyak 1 siswa atau 3,3\%, siswa yang mendapat nilai > 70 yaitu sebanyak 32 siswa atau 9,7\%. Berarti kemampuan siswa kelas VII SMP N 2 Buay Bahuga, Lampungmenulis karangan narasi dari siklus 1 sampai siklus 2 mengalami peningkatan yang signifikan.

Siswa kelas VII SMP N 2 Buay Bahuga, Lampung sebagian besar 1) senang mendapatkan pelajaran mengarang; 2) sering mengarang di luar jam pelajaran; 3) lebih menyenangkan menggunakan metode pembelajaran inquiri dibandingkan dengan ceramah; 4) mengaku lebih mudah menulis karangan jenis narasi; 5) 
Upaya Meningkatkan Menulis.... (Eppy Marlina)

mengakui lebih mudah menggunakan model pembelajaran inquiri; 6) mengakui setuju untuk menggunakan metode pembelajaran inquiri saat pembelajaran mengarang; 7) mengakui model pembelajaran inquiri bermanfaat saat pembelajaran mengarang; 8) mengakui tidak sulit menggunakan model pembelajaran inquiri saat pembelajaran mengarang.

\section{PEMBAHASAN}

Penelitian dilaksanakan pada tanggal 13 Oktober sampai dengan 23 Oktober 2015 bertempat di SMP N 2 Buay Bahuga, Lampung pada siswa kelas VII dengan menggunakan metode penelitian tindakan kelas yang berakhir pada siklus II. Pada setiap siklus dibagi dalam 4 (empat) kegiatan yaitu: perencanaan, pelaksanaan, observasi, evaluasi dan refleksi.

Perbaikan kelemahan siswa dalam menulis karangan narasi mendapat hasil memuaskan dilakukan dari prasiklus sampai siklus II. Pada saat prasiklus jumlah siswa yang tuntas adalah 9 siswa atau 27\%. Pada siklus I, meningkat menjadi 19 siswa atau 57,5\% dengan nilai rata-rata 71,9. Kemudian pada siklus II jumlah siswa yang tuntas meningkat menjadi 32 siswa atau 96,7\% dengan nilai rata-rata 76,96. Berarti kemampuan siswa kelas VII SMP N 2 Buay Bahuga, Lampung menulis karangan narasi dari siklus 1 sampai siklus 2 mengalami peningkatan yang signifikan.

\section{SIMPULAN}

Berdasarkan uraian yang telah dipaparkan, maka dapat ditarik simpulan bahwa pelaksanaan pembelajaran dengan menggunakan model pembelajaran inquiri pada materi pembelajaran menulis karangan narasi, telah terlaksana dengan baik dan dapat membantu siswa dalam mengembangkan imajinasinya serta meningkatkan keterampilan siswa dalam menulis karangan narasi, hal tersebut dapat dilihat dari data-data nilai pada setiap siklus yang menunjukkan peningkatan yang cukup signifikan dari prasiklus sampai siklus II. Persentase jumlah siswa yang tuntas pada saat prasiklus adalah 9 siswa atau 27\%. Setelah 
dilakukan tindakan pada siklus I, meningkat menjadi 19 siswa atau 57,5\% dengan nilai rata-rata 71,9. Kemudian pada siklus II jumlah siswa yang tuntas meningkat menjadi 32 siswa atau 96,7\% dengan nilai rata-rata 76,96.

\section{DAFTAR PUSTAKA}

Armariena, D. N. (2015). Pengaruh Strategi Herringbone dan Kemampuan Berpikir Kritis terhadap Kemampuan Menulis Karangan Argumentasi Siswa Kelas VII SMP Negeri 45 Palembang. Jurnal Dosen Universitas PGRI Palembang.

Armariena, D. N. (2017). Penulisan Narasi Mahasiswa dengan Metode Copy teh Master dalam Menghidupkan Kartakter, Perilaku dan Konflik Tokoh. Prosiding Dosen Universitas PGRI Palembang Edisi 9, 10-19. Palembang: Universitas PGRI Palembang.

Armariena, D. N. (2019). Penulisan Karangan Argumentasi Dengan Strategi Herringbone dan Kemampuan Berpikir Kritis Mahasiswa. Jurnal Wahana Didaktika. Vol 17 No 1 Januari 2019.

Armariena, D. N. (2019). Penulisan Makalah Mahasiswa pada MKU Bahasa Indonesia dengan Metode Mind Mapping. Jurnal Wahana Didaktika. Vol 17 No 2 Mei 2019.

Keraf, Gorys. (2001). Menulis Efektif. Jakarta : Gramedia

Kusumaningsih, Dewi dkk. (2013). Terampil Berbahasa Indonesia. Yogyakarta: Penerbit Andi.

Sadiman, Arief S. (2003). Media Pendidikan: Pengertian,Pengembangan dan Pemanfaatannya. Jakarta: Raja Grafindo

Slamet, St.Y. (2007). Dasar-Dasar Keterampilan Berbahasa Indonesia. Surakarta: Universitas Sebelas Maret Press.

Semi. M. Atar. (2007). Dasar-Dasar Keterampilan Menulis. Bandung: Angkasa. 